\title{
Sonic Hedgehog in cancer stem cells: a novel link with autophagy
}

\author{
Luis A. Milla ${ }^{1}$, Claudia N. González-Ramírez ${ }^{1}$, Verónica Palma1* \\ ' Center for Genome Regulation, Laboratory of Stem Cells and Development, Faculty of Sciences, University of Chile, Nuñoa, Chile \\ Faculty of Sciences, University of Chile, Las Palm eras 3425 Ñuñoa.
}

\begin{abstract}
The Sonic Hegdehog/GLI (SHH/GLI) pathway has been extensively studied for its role in developmental and cancer biology. During early embryonic development the SHH pathway is involved mainly in pattern formation, while in latter stages its function in stem cell and progenitor proliferation becomes increasingly relevant. During postnatal development and in adult tissues, SHH/GLI promotes cell homeostasis by actively regulating gene transcription, recapitulating the function observed during normal tissue growth. In this review, we will briefly discuss the fundamental importance of SHH/GLI in tumor growth and cancer evolution and we will then provide insights into a possible novel mechanism of SHH action in cancer through autophagy modulation in cancer stem cells. Autophagy is a homeostatic mechanism that when disrupted can promote and accelerate tumor progression in both cancer cells and the stroma that harbors tumorigenesis. Understanding possible new targets for SHH signaling and its contribution to cancer through modulation of autophagy might provide better strategies in order to design combined treatments and perform clinical trials.
\end{abstract}

Key words: Cancer Stem Cells, Sonic Hedgehog, Cell Survival, Autophagy, neuroblastoma, cancer therapy

There are several developmentally expressed signaling molecules that have relevance in tumorigenesis and cancer. One of them, the hedgehog $(\mathrm{HH})$ pathway, plays a key role in the regulation of embryonic development and governs processes such as cell differentiation, cell proliferation and tissue patterning. In the adult, Sonic Hedgehog, the most studied member of the vertebrate $\mathrm{HH}$ family, functions in tissue repair and regeneration, along with maintenance of stem cells. In adult tissues, $\mathrm{SHH}$ can recapitulate the gene expression that is achieved during embryogenesis through the selective activation of transcription factors. In recent years the number of identified genes that are directly regulated by the $\mathrm{SHH}$ pathway has increased, and can be related to oncogenic processes since several of the new targets are implicated in cancer biology (Table 1). Here, we will shortly summarize the multifaceted potential of $\mathrm{SHH}$ in tumor growth and maintenance according to the current literature. We will then focus on a previously unreported process controlled by $\mathrm{SHH}$, autophagy, and propose an intriguing connection between a pivotal growth factor and a key cellular response as an emerging therapy that could be targeted to induce tumor cell death.

\section{THE SHH/GLI PATHWAY AT A GLANCE}

$\mathrm{SHH}$ is a secreted glycoprotein that activates signaling in target cells by binding to its 12-pass transmembrane receptor Patched 1 (Ptc/Ptch), which unleashes Smoothened (Smo), a sevenpass transmembrane protein G-coupled co-receptor to trigger downstream activation of the GLI family transcription factors. In mammals, canonical $\mathrm{SHH}$ signaling promotes localization of Smo to the primary cilium, a microtubule-based specialized cell surface protrusion, considered today a critical organizer for molecules involved in SHH signaling in vertebrates (Goetz et al., 2009, Ezratty et al., 2011). SHH ultimately exerts its effects by influencing the balance between GLI activator and repressor forms. Smo activation leads to the stabilization of GLI3 transcription factor, that, together with GLI2, act as the canonical effectors activating gli1 and other target genes. In the absence of SHH, GLI3, and, to a lesser extent, GLI2 truncated forms can mediate in transcription acting as repressors (AzaBlanc et al., 2000).

\section{SHH/ GLI PATHWAY IN CANCER}

Altered SHH pathway activation, as revealed by upregulation of gli1 or patched1 expression, has been involved in different types of solid and non-solid cancers, including glioma, medulloblastoma, neuroblastoma, leukemia, gastric cancer, and other tumors (Katoh and Katoh, 2009). Indeed, aberrant activity of $\mathrm{SHH}$ has been extensively connected to different aspects of cancer development, from tumorigenesis to metastasis. Accordingly, recent clinical trials with $\mathrm{Hh}$ pathway antagonists have validated this pathway as a promising anticancer target. Next, we will review the role of $\mathrm{SHH}$ in cancer pathogenesis, in particular how $\mathrm{SHH}$ impacts to promote and maintain malignancy from normal tissue to tumors focusing on diverse aspects of gene regulation ranging from tumor initiation, invasiveness promotion to nutrient recycling by autophagy.

\section{INITIATION}

There has been a long debate to describe the initiation cells that give rise to cancer. Even though the classification of cancers is relatively direct, the understanding of the ontogenetic origin of cancer remains elusive. One reason is that every cancer is different in terms of originating tissue, formation, and gene expression (Ezratty et al., 2011). It has been proposed that cancer initiates with a small number of "stem cells", that have the capacity to replenish the tumor in its entirety (Hill and Wu, 2009). Cancer stem-like cells (CSCs) have been identified 
TABLE 1

$\mathrm{SHH}$ targets associated to cancer. State-of-the-art listing of SHH-GLI controlled genes related to tumorigenesis and tumor progression

\begin{tabular}{|c|c|c|c|}
\hline Target gene & Function in cancer & Regulation & Reference \\
\hline Ascl1 & $\begin{array}{l}\text { Neurogenic bHLH transcription factor, gene } \\
\text { regulation }\end{array}$ & Direct & (Voronova et al., 2011) \\
\hline Bcl-2 & Antiapoptotic protein, cell survival & Direct & (Bigelow et al., 2004) \\
\hline Bmil & Stem cell marker & Direct & (Wang et al., 2012) \\
\hline Cyclin D1 & Cell cycle & Direct & (Hu et al., 2006) \\
\hline Cyclin D2 & Cell cycle & Direct & (Yoon et al., 2002; Yoon et al., 2009) \\
\hline cyr61 & Pro-angiogenic factor & Direct & (Harris et al., 2011) \\
\hline DNMT1 & Epigenetic gene regulation & Direct & (He et al., 2011) \\
\hline Fgf15 & CNS development & Direct & (Komada et al., 2008) \\
\hline FOXA2 (HNF3 $\beta)$ & Transcriptional activator in liver & Direct & (Sasaki et al., 1997) \\
\hline FoxF1 & $\begin{array}{l}\text { Mesenchymal transcription factor and potential } \\
\text { tumor suppressor }\end{array}$ & Direct & (Madison et al., 2009) \\
\hline FoxL1 & Mesenchymal transcription factor & Direct & (Madison et al., 2009) \\
\hline Hes 1 & Transcriptional repressor, Notch target & Direct & (Wall et al., 2009) \\
\hline Hhip & Hedgehog interacting protein & Direct & (Vokes et al., 2007) \\
\hline Hrt3 & Notch target & Indirect & (Morrow et al., 2009) \\
\hline IGFBP3 & Igf binding protein & Direct & (Yu et al., 2009) \\
\hline IGFBP6 & Igf binding protein & Direct & (Yu et al., 2009) \\
\hline Myf5 & Muscle differentiation & Direct & (Gustafsson et al., 2002) \\
\hline Nkx2.1 & Potential oncogene & Direct & (Vokes et al., 2007) \\
\hline $\mathrm{Nkx} 2.2$ & Potential oncogene & Direct & (Vokes et al., 2007) \\
\hline Osteopontin & EMT regulation & Direct & (Yoon et al., 2002; Das et al., 2009) \\
\hline $\operatorname{Pax} 2$ & Tumor suppressor target gene & Direct & (Hu et al., 2006) \\
\hline Plakoglobin & Catenin-cadherin complex, EMT & Direct & (Yoon et al., 2002) \\
\hline \multirow[t]{2}{*}{ Ptch1 } & Catenin-cadherin complex, EMT & Direct & (Yoon et al., 2002) \\
\hline & Negative regulator of $\mathrm{Hh}$ & Direct & (Alexandre et al., 1996) \\
\hline Ptch2 & Patched homolog & Direct & (Vokes et al., 2007) \\
\hline RegIV & Multiple functions in cancer & Direct & (Wang et al., 2011) \\
\hline RGS4 & G protein regulator & Direct & (Yu et al., 2009) \\
\hline Sall1 & Transcription factor involved in tumorigenesis & Direct & (Hu et al., 2006) \\
\hline Sox9 & $\begin{array}{l}\text { Transcription factor involved in development and } \\
\text { oncogenesis }\end{array}$ & Direct & (Bien-Willner et al., 2007) \\
\hline Stathmin 1 & Microtubule dynamic-regulating oncoprotein & Non determined & (Chung et al., 2010) \\
\hline
\end{tabular}


in solid tumors of the breast, colon, brain and other sites. They can differentiate into all the cell phenotypes of the parental tumor. This developmental scheme has been demonstrated for many cancer types, including neural (Hemmati et al., 2003) and non-neural tumors (Richardson et al., 2004, O'Brien et al., 2007). The origin of CSCs is not fully understood, but data suggest that they originate from normal stem or progenitor cells, or possibly other cancer cells. These cells are capable to self-renewal, to give rise the different tumor cell types, and to maintain tumor growth. Other key features include activation of pluripotency genes (Oct4, Sox2, Nanog), formation of tumor spheres in low-adherence cultures, and multi-drug resistance. CSCs can be identified by distinct markers, including the cell surface marker CD133 (also known as prominin 1), BMI1 and CD44 (Neuzil et al., 2007) [Figure 1 and Table 1]. Noteworthy, these cells have been shown as resistant to cancer therapies and CSCs have therefore been proposed to be the cells of origin for tumor relapse. Thus, while the transcriptome of CSCs may not fully match that of the cognate stem cells, pluripotent tumor cells with stem cell phenotype and capacity probably contribute significantly to the phenotypic heterogeneity seen in cancers.

CSCs use a variety of signaling pathways to undergo self-renewal and differentiation, including Wnt, Notch, and HH (Barker and Clevers, 2006; Wang et al., 2012a). There is increasing evidence that connects the SHH/GLI pathway and tumor initiation specific markers as targets (Katoh and Katoh, 2009). In neuroblastoma, for instance, a SHH pathway pharmacological loss of function reduces a CD133/ CD15 positive compartment (Schiapparelli et al., 2011). In medulloblastoma, stem cell markers have been involved in SHH tumor propagation (Read et al., 2009), and are also directly controlled by the pathway (Wang et al., 2012). Thus, the SHH/GLI pathway may have different roles during cancer initiation, activating in cells with tumorigenic potential, and up-regulating genes that are involved in cell "stemness" maintenance.

\section{GROWTH}

The SHH pathway has been classically involved in growth during embryonic development, controlling key genes that modulate cell proliferation such as cyclins and $n$-myc (Figure 1). Abnormal SHH signaling activity during cancer has similarities to normal development and organ growth; tumor cells recapitulate development, but aberrantly. Gain of function mutations in key components of the $\mathrm{SHH}$ pathway, such as Patched 1 or Smo, are sufficient to generate tumors in different tissues such as skin, cerebellum and prostate (Athar et al., 2006, Yang et al., 2008, Sanchez et al., 2004). SHH controls genes (Mill et al., 2005), both directly and indirectly, that amplify a secondary response signal, since many of these target genes control their own multiple targets (Eilers and Eisenman, 2008).

\section{MAINTENANCE}

During embryonic development and in normal tissue homeostasis, $\mathrm{SHH}$ is involved in progenitor cell maintenance and has also been shown to act as a survival factor in different

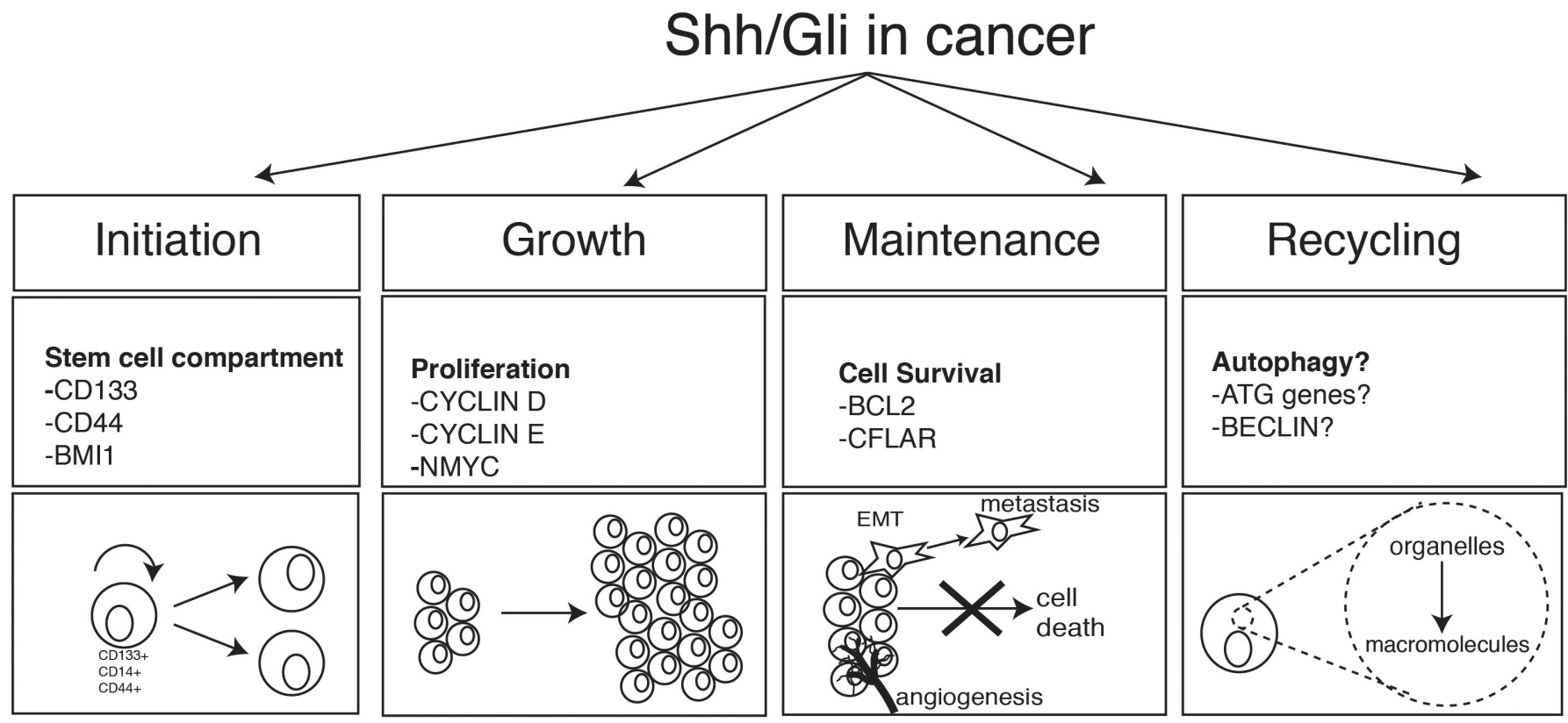

Figure 1: SHH functions in cancer. The canonical SHH pathway has been related to many aspects of tumorigenesis and tumor progression. During cancer initiation, there is a SHH/GLI dependent up-regulation of the CSC marker BMI1, sharing expression with CD15 or CD133. $\mathrm{SHH}$ is also involved in maintaining the stem cell niche responsible for tumor initiation. Later on, during tumor growth $\mathrm{SHH} / \mathrm{GLI}$ controls transcription of genes implicated in cell proliferation and cell cycle progression. In order to maintain tumor size and support pro-invasive processes, SHH pathway activates cell survival, EMT transition, angiogenesis and metastatic mechanisms through extensive direct gene regulation. $\mathrm{SHH}$ is also acting indirectly related to other signaling pathways. We propose that SHH could be involved in the autophagic process as a way to recycle nutrients, promoting cell survival and resistance to adverse environments. All these functions highlight the importance of the SHH pathway in cancer biology and justify its use as a strategic target for combined pharmacologic treatments. 
tissues (Krüger et al., 2001; Machold et al., 2003). In cancer progression, both processes are deregulated, implicating $\mathrm{SHH}$ dysfunction. In order to maintain the number of cells growing in a tumor, $\mathrm{SHH}$ can control cell death avoidance/survival. Canonical SHH signaling positively controls bcl-2 (Bigelow et al., 2004), an important regulator of apoptosis and protooncogene that has been related to cell survival in multiple solid and non-solid cancers. SHH also modulates apoptosis induced by the Tumor necrosis factor-related apoptosis-inducing ligand (TRAIL) through repression by GLI3, binding the cognate death receptor-4 (DR4) promoter (Kurita et al., 2010).

\section{ANGIOGENESIS}

The term angiogenesis literally means "new blood vessel formation", and performs a critical role for cancer progression that facilitates tumor growth and survival. Angiogenesis enables tumor expansion, local expansion and dissemination (Bergers and Benjamin, 2003). It is a well-regulated process, driven by specific pro-angiogenic factors and extracellular proteins expressed by endothelial cells (Schmidt et al., 2007). Pro-angiogenic factors such as cyr61, VEGF, neuropilin-1 and CD24 have recently been shown as regulated by the canonical $\mathrm{SHH}$ pathway. SHH appears to play a critical part in the biology of the perivascular niche and has been implicated in vascular formation and function within the tumor (Harris et al., 2011; Cao et al., 2012, Geng et al., 2007). Of note, the angiogenic process is closely related to other massive changes in cancer cells, in order to promote colonization of new niches.

\section{EPITHELIAL MESENCHYMAL TRANSITION (EMT) AND ME-} TASTASIS

EMT refers to a cellular reorganization process that is key to embryonic development. It results in down-regulation of cell adhesive mechanisms, loss of cell polarity, and gaining of invasive and migratory mesenchymal properties. The EMT series of events also occur during tumorigenesis, allowing tumor-initiating cells to metastasize. During EMT, cells downregulate E-cadherin, a membrane-bound glycoprotein involved in the adherence of adjacent cells. The loss of E-cadherin in primary tumor tissue has been linked to tumor metastasis and poor prognosis. SHH is involved in EMT along with Notch and BMP signaling pathways and other niche factors, such as members of the transforming growth factor- $\beta$ (TGF- $\beta$ ) superfamily of cytokines (Bailey et al., 2007; Yoo et al., 2011). These different pathways are also connected, since $\mathrm{SHH}$ for instance, directly upregulates Jagged2 to activate the Notch pathway response (Kasper et al., 2006). SHH also regulates the expression of other proteins involved in EMT and metastasis as Snail (Wanshura et al., 2011) and the down-regulation of E-cadherin, contributing to the EMT and metastatic phenotype (Maitah et al., 2011).

\section{AUTOPHAGY AS A MECHANISM FOR SELECTIVE TUMOR} GROWTH

Tumor cells often acquire the ability to evade death by inactivating survival pathways that normally function to eliminate damaged and harmful cells. A strictly regulated mechanism that achieves this removal and reutilization is autophagy. Autophagy is generally thought to play a pro- survival role and can be up-regulated in response to both external and intracellular factors, including amino acid starvation, growth factor withdrawal, low cellular energy levels, endoplasmic reticulum (ER) stress, hypoxia, oxidative stress, pathogen infection, and organelle damage (Janku et al., 2011). It is therefore considered a self-defense mechanism, where macromolecules and complete organelles are engulfed in perinuclear double membrane vesicles and degraded in lysosomes (Mizushima, 2007; Chen and White, 2011).

The role of autophagy in cancer is complex, depending mainly on the tumor stage. It has been proposed that autophagy may have a dual role, as a tumor suppressor in normal cells by degrading oncoproteins and, later, allowing cancer cells to survive during metabolic stress (Janku et al., 2011). In this sense, although autophagy is a mechanism of tumor suppression, it also confers stress tolerance that enables tumor cells to survive under adverse conditions by recycling of nutrients for metabolic needs, a fundamental aspect of tumor progression. It has been observed that extensive autophagy is generated by tumor hypoxia and anaerobic glycolysis, whereas angiogenesis maintains low autophagic activity. In fact, autophagy localizes to hypoxic regions of tumors most distal to blood vessels where is supports tumor cell survival (Sivridis et al., 2011).

Autophagy inhibition may result an interesting strategy for pharmacological studies in order to limit tumor nutrient availability and energy demands. The successful development and application of autophagy regulators is important. Signaling pathways that promote autophagy are therefore potential candidates for inhibitor development.

\section{A NEW PARADIGM FOR SHH/GLI THERAPEUTIC ACTION: IN- HIBITION OF AUTOPHAGY WITH HH INHIBITORS}

To date, a relationship between the SHH and autophagy pathways has not been reported, although it has been shown that there are cancers that are sensitive to both pathways, as for instance neuroblastoma (Mao et al., 2009; Mohan et al., 2011; Xu et al., 2012).

In order to shed light on a possible link between $\mathrm{SHH}$ and autophagy we tested the effect of a pharmacological loss of function for the SHH pathway in the number of LC3 [microtubule-associated protein light chain 3] positive vesicles, using the neuroblastoma cell line SHSY5Y (Biedler et al., 1978). To date, the detection of processed LC3 by western blot or fluorescence studies, together with electron microscopy for autophagosome formation, have been the mainstays for autophagy detection (Lazova et al., 2010). Cyclopamine (cyc), an alkaloid that functions as SHH antagonist, with several derivatives under clinical trials, was used under a nutrient starvation protocol consisting of serum starvation (Allison, 2012). Two hours of cyc pretreatment of SHSY5Y cultures prevented LC3 vesicles formation (Figure 2A-B). This reduction in LC3 autophagosome positive cells was accompanied with increased Caspase 3 positive cells, suggesting that these cells underwent apoptosis, probably also related to genes controlled by SHH/GLI (Figure 2D-H). To evaluate if the $\mathrm{SHH}$ pathway controls essential autophagic genes such as atg5 or beclin1 (bcn1), we used a SHH-sensitive cell line, C3H10T1/2, treated with SHH-N conditioned media or control $(\Delta 64-\mathrm{SHH})$ and evaluated $\operatorname{atg} 5$ and $b c n 1$ levels. Pathway activation was monitored by $p t c 1$. Of note, atg5 decreased in 
$\Delta 64-\mathrm{SHH}$ treated cells, whereas bcn1 did not change under these conditions. This suggests that autophagy regulation by $\mathrm{SHH}$ could be driven by a transcripcional control of specific key autophagic genes. Importantly, using a yeast-reverse one-hybrid system (Milla et al., 2012) and bioinformatics we were able to detect non -consensus GLI binding sites (GBS) in the first and seventh intron of the mouse atg5. We also found multiple GBS in the human ATG5 promoter (unpublished
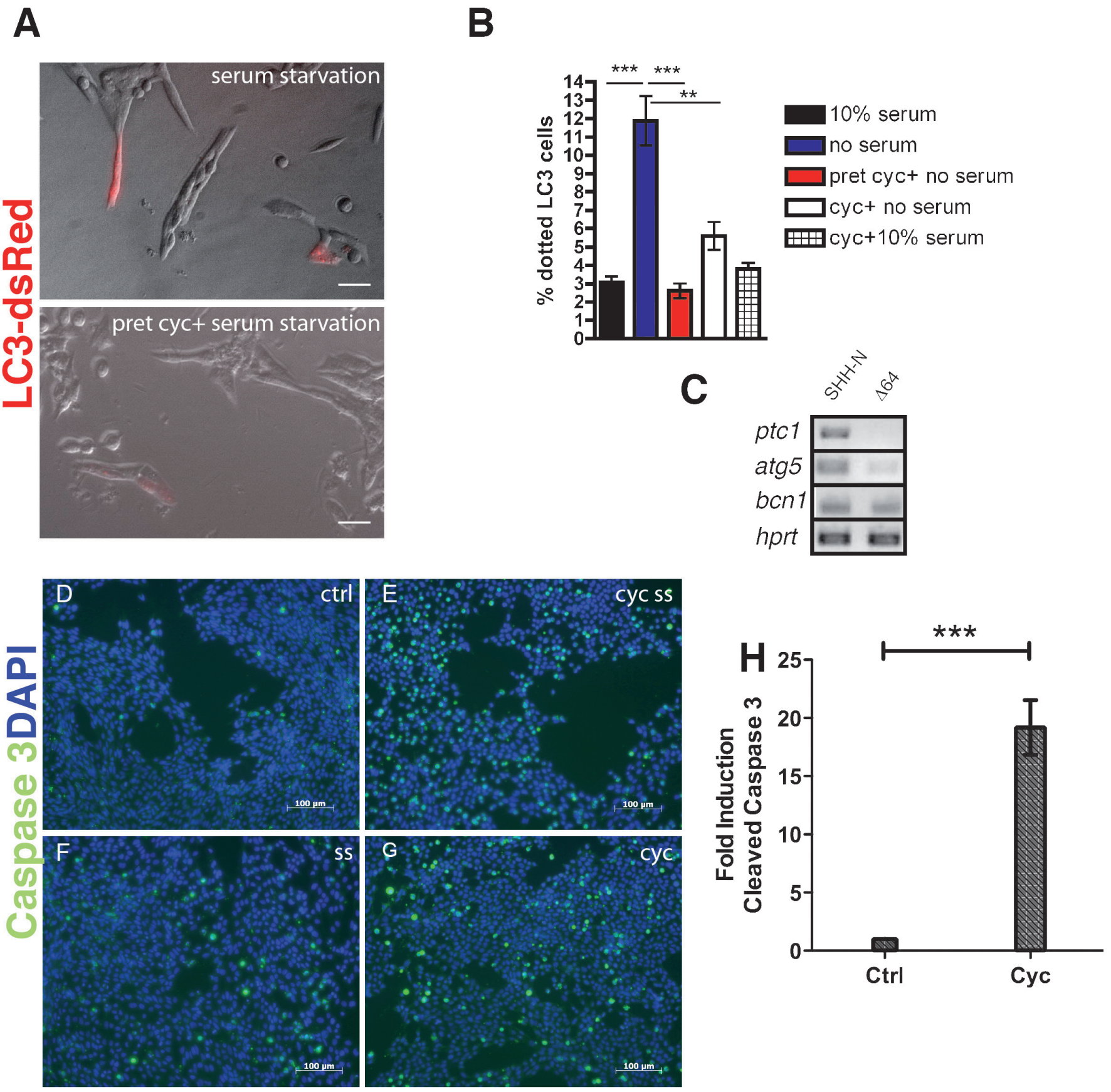

Figure 2: SHH signaling regulates autophagy in the neuroblastoma cell line SHSY5Y. 6-hour serum-starved cells increase dotted LC3DsRed positive cells in comparison to $10 \%$ fetal bovine serum cultured controls, suggesting increased autophagy (A-B). Treatment with $10 \mu \mathrm{M}$ cyc significantly decreases the number of LC3-dotted cells compared to the control serum-starved condition. Strikingly, the decrease in LC3 positive cells after a 2-hour cyc pre-treatment is even more pronounced (B). Representative images of replicates of 4 experiments are shown in upper and lower panel. Bar=50 $\mu \mathrm{m}$. (C) The SHH pathway reporter cell line C3H10T1/2 were treated for 24 hours with conditioned media obtained following 48-hour transfection of C3H10T1/2 cells with either SHH-N or $\Delta 64-\mathrm{SHH}$, a mutant form of Shh, which is unable to signal. Pathway activation was monitored by ptc 1 . Note the atg 5 decrease in $\Delta 64-\mathrm{SHH}$ treated cells. The bcn 1 autophagic gene does not change under these conditions. (D-G), Cyc treatment drives cells to apoptosis as evidenced by an increased number of cleaved caspase 3-positive cells $\mathrm{p}<0.0006$. Quantitation in $(\mathrm{H})$. Each bar in the graph represents the average of separate triplicate determinations showing the standard deviation of the mean. $\mathrm{P}$ value $\mathrm{p}<0.001$. 
results). These data suggest the attractive possibility that $\mathrm{SHH}$ pathway might control the autophagic series of events in cancer cells. From a therapeutic point of view, it would be interesting to evaluate the effect of combined anticancer pharmacological antiautophagic agents and $\mathrm{Hh}$ pathway inhibition on tumor cell survival. $\mathrm{SHH}$ pathway inhibition could act as a novel sensitizer to increase efficiency of conventional chemotherapeutic agents in cancer by inducing apoptosis. Consistent with our findings, previous reports have suggested that several cytotoxic chemotherapeutic agents induce autophagy, and inhibition of autophagy enhanced their efficiency in vitro (Guo et al., 2012). Combinations of other anticancer drugs with autophagy inhibitors have also shown success in preclinical models (Amaravadi et al., 2007, Carew et al., 2010).

Autophagy could also act in the cells that fuel the tumor, especially in the early stages, modulating the tumor stroma or the "stem cell niche". Tumor cells exploit the surrounding stromal environment through the recruitment of these nonmalignant cells that provide physiological resources to facilitate tumor progression. It has been proposed that the stromal cells increase autophagy in order to speed their metabolism and generate anaerobic extra-mitochondrial glycolisis, allowing them to boost their energy production and oxidative stress, accelerating a random mutagenesis in cancer cells (Lisanti et al., 2010). We only analyzed the changes in neuroblastoma cells produced by the $\mathrm{SHH}$ pathway, it is important, however, to conceive these changes as cooperative and strongly related to the tumor microenvironment, occurring in parallel during each tumor stage. Experiments conducted using co-cultures, as a model, would help to understand this relationship and shed light on the in vivo situation. Even though autophagy plays a similar role in tumor cells as it does in normal cells, tumor cells face more stress and the dependence on autophagy may be more substantial. This differential response between normal and tumor cells in autophagy dependence may be useful for exploiting autophagy modulation in cancer therapy. In tumor initiation, for example, autophagy should be studied in the tumor-initiating cells and in the tumor niche, the stroma, in an independent manner.

Cross talk between independent yet intertwined signaling pathways of metabolism and cancer is currently a topic of intense research. Of note, $\mathrm{SHH}$ has recently been proposed as a general positive metabolic regulator in cancer (Bhatia et al., 2012). This observation, combined with our data indicating a $\mathrm{SHH}$ mediated autophagic activation, could influence cancer cells to survive and proliferate. More elaborate analysis is needed to determine if the $\mathrm{SHH}$ and autophagic pathways activation are coupled in different cancer types.

\section{CONCLUDING REMARKS}

Induction of cell death and inhibition of growth are the main targets of cancer therapy. In this short paper, we summarized new insights into molecular mechanisms of $\mathrm{SHH}$ action in cancer with special focus on autophagy. Understanding the role of autophagy in cancer treatment is critical since many anticancer therapies activate autophagy, possibly limiting their therapeutic efficacy. Here we propose that autophagy could be connected with the $\mathrm{HH}$ signaling pathway. The nature of this relation is of interest for the design of anticancer combined therapies, with $\mathrm{HH}$ and autophagy antagonists. Elucidating the interplay between autophagy, tumor cell metabolism and $\mathrm{SHH} / \mathrm{GLI}$ will provide unique opportunities to identify new therapeutic targets and develop synthetically lethal treatment strategies that preferentially target cancer cells, while sparing normal tissues.

\section{ACKNOWLEDGEMENTS}

We would like to thank Dr. Alvaro Glavic for critical reading of the manuscript and Pablo Lois for technical assistance. We would also like to give a special thanks to the Pew Foundation for their support. This work was supported by FONDAP 15090007 (VP), Fondecyt grant 1110237 (VP), Fondecyt Postdoctoral 3100045 (LAM).

\section{REFERENCES}

ALEXANDRE, C., JACINTO, A., AND INGHAM, P.W. (1996). Transcriptional activation of hedgehog target genes in Drosophila is mediated directly by the cubitus interruptus protein, a member of the GLI family of zinc finger DNA-binding proteins. Genes Dev. 10, 2003-2013.

ALLISON, M. (2012). Hedgehog hopes lifted by approval... and stung by failure. Nature Biotechnology 30, 203-203.

AMARAVADI, R.K., YU, D., LUM, J.J., BUI, T., CHRISTOPHOROU, M.A., EVAN, G.I., THOMAS-TIKHONENKO, A., AND THOMPSON, C.B. (2007). Autophagy inhibition enhances therapy-induced apoptosis in a Myc-induced model of lymphoma. J. Clin. Invest. 117, 326-336.

ATHAR, M., TANG, X., LEE, J.L., KOPELOVICH, L., AND KIM, A.L. (2006). Hedgehog signalling in skin development and cancer. Exp. Dermatol. 15, 667-677.

AZA-BLANC, P., LIN, H.Y., RUIZ I ALTABA, A., AND KORNBERG, T.B. (2000). Expression of the vertebrate Gli proteins in Drosophila reveals a distribution of activator and repressor activities. Development 127, $4293-4301$.

BAILEY, J.M., SINGH, P.K., AND HOLLINGSWORTH, M.A. (2007). Cancer metastasis facilitated by developmental pathways: Sonic hedgehog, Notch, and bone morphogenic proteins. J. Cell. Biochem. 102, 829-839.

BERGERS, G., AND BENJAMIN, L.E. (2003). Tumorigenesis and the angiogenic switch. Nat. Rev. Cancer 3, 401-410.

BHATIA, B., POTTS, C.R., GULDAL, C., CHOI, S., KORSHUNOV, A., PFISTER, S., KENNEY, A.M., AND NAHLÉ, Z.A. (2012). Hedgehogmediated regulation of PPAR $\gamma$ controls metabolic patterns in neural precursors and shh-driven medulloblastoma. Acta Neuropathol. 123, $587-600$.

BIANCHI, N., DEPIANTO, D., MCGOWAN, K., GU, C., AND COULOMBE, P.A. (2005). Exploiting the keratin 17 gene promoter to visualize live cells in epithelial appendages of mice. Mol. Cell. Biol. 25, 7249-7259.

BIEDLER, J.L., ROFFLER-TARLOV, S., SCHACHNER, M., AND FREEDMAN, L.S. (1978). Multiple neurotransmitter synthesis by human neuroblastoma cell lines and clones. Cancer Res. 38, 3751-3757.

BIEN-WILLNER, G.A., STANKIEWICZ, P., AND LUPSKI, J.R. (2007). SOX9cre1, a cis-acting regulatory element located $1.1 \mathrm{Mb}$ upstream of SOX9, mediates its enhancement through the SHH pathway. Hum. Mol. Genet. 16, 1143-1156.

BIGELOW, R.L.H., CHARI, N.S., UNDEN, A.B., SPURGERS, K.B., LEE, S., ROOP, D.R., TOFTGARD, R., AND MCDONNELL, T.J. (2004). Transcriptional regulation of bcl-2 mediated by the sonic hedgehog signaling pathway through gli-1. J. Biol. Chem. 279, 1197-1205.

CAO, X., GERADTS, J., DEWHIRST, M.W., AND LO, H.-W. (2012) Upregulation of VEGF-A and CD24 gene expression by the tGLI1 transcription factor contributes to the aggressive behavior of breast cancer cells. Oncogene 31, 104-115.

CAREW, J.S., MEDINA, E.C., ESQUIVEL, J.A., 2ND, MAHALINGAM, D., SWORDS, R., KELLY, K., ZHANG, H., HUANG, P., MITA, A.C., MITA, M.M., ET AL. (2010). Autophagy inhibition enhances vorinostat-induced apoptosis via ubiquitinated protein accumulation. J. Cell. Mol. Med. 14, $2448-2459$

CHEN, H.-Y., AND WHITE, E. (2011). Role of autophagy in cancer prevention. Cancer Prev Res (Phila) 4, 973-983.

CHEN, M., FEUERSTEIN, M.A., LEVINA, E., BAGHEL, P.S., CARKNER, R.D., TANNER, M.J., SHTUTMAN, M., VACHEROT, F., TERRY, S., 
DE LA TAILLE, A., ET AL. (2010). Hedgehog/Gli supports androgen signaling in androgen deprived and androgen independent prostate cancer cells. Mol. Cancer 9, 89 .

CHUNG, M.-K., KIM, H.-J., LEE, Y.-S., HAN, M.-E., YOON, S., BAEK, S.Y., KIM, B.-S., KIM, J.-B., AND OH, S.-O. (2010). Hedgehog signaling regulates proliferation of prostate cancer cells via stathmin1. Clin. Exp. Med. 10, 51-57.

DAS, S., HARRIS, L.G., METGE, B.J., LIU, S., RIKER, A.I., SAMANT, R.S., AND SHEVDE, L.A. (2009). The hedgehog pathway transcription factor GLI1 promotes malignant behavior of cancer cells by up-regulating osteopontin. J. Biol. Chem. 284, 22888-22897.

EILERS, M., AND EISENMAN, R.N. (2008). Myc's broad reach. Genes Dev. 22, 2755-2766.

EZRATTY, E.J., STOKES, N., CHAI, S., SHAH, A.S., WILLIAMS, S.E., AND FUCHS, E. (2011). A role for the primary cilium in Notch signaling and epidermal differentiation during skin development. Cell 145, 1129-1141.

GENG, L., CUNEO, K.C., COOPER, M.K., WANG, H., SEKHAR, K., FU, A., AND HALLAHAN, D.E. (2007). Hedgehog signaling in the murine melanoma microenvironment. Angiogenesis 10, 259-267.

GOETZ, S.C., OCBINA, P.J.R., AND ANDERSON, K.V. (2009). The primary cilium as a Hedgehog signal transduction machine. Methods Cell Biol. 94, 199-222.

GUO, X.-L., LI, D., HU, F., SONG, J.-R., ZHANG, S.-S., DENG, W.J., SUN, K., ZHAO, Q.-D., XIE, X.-Q., SONG, Y.-J., ET AL. (2012). Targeting autophagy potentiates chemotherapy-induced apoptosis and proliferation inhibition in hepatocarcinoma cells. Cancer Letters.

GUSTAFSSON, M.K., PAN, H., PINNEY, D.F., LIU, Y., LEWANDOWSKI, A., EPSTEIN, D.J., AND EMERSON, C.P., JR (2002). Myf5 is a direct target of long-range Shh signaling and Gli regulation for muscle specification. Genes Dev. 16, 114-126.

HARRIS, L.G., PANNELL, L.K., SINGH, S., SAMANT, R.S., AND SHEVDE, L.A. (2011). Increased vascularity and spontaneous metastasis of breast cancer by hedgehog signaling mediated upregulation of cyr61. Oncogene.

HE, S., WANG, F., YANG, L., GUO, C., WAN, R., KE, A., XU, L., HU, G., XU, X., SHEN, J., ET AL. (2011). Expression of DNMT1 and DNMT3a are regulated by GLI1 in human pancreatic cancer. PLoS ONE 6, e27684.

HEMMATI, H.D., NAKANO, I., LAZAREFF, J.A., MASTERMAN-SMITH, M., GESCHWIND, D.H., BRONNER-FRASER, M., AND KORNBLUM, H.I. (2003). Cancerous stem cells can arise from pediatric brain tumors. Pnas 100, 15178-15183.

HILL, R., AND WU, H. (2009). PTEN, Stem Cells, and Cancer Stem Cells. J. Biol. Chem. 284, 11755-11759.

HU, M.C., MO, R., BHELLA, S., WILSON, C.W., CHUANG, P.-T., HUI, C.C., AND ROSENBLUM, N.D. (2006). GLI3-dependent transcriptional repression of Gli1, Gli2 and kidney patterning genes disrupts renal morphogenesis. Development 133, 569-578.

HWANG, J.-H., LEE, S.H., LEE, K.H., LEE, K.Y., KIM, H., RYU, J.K., YOON, Y.B., AND KIM, Y.-T. (2009). Cathepsin B is a target of Hedgehog signaling in pancreatic cancer. Cancer Lett. 273, 266-272.

JANKU, F., MCCONKEY, D.J., HONG, D.S., AND KURZROCK, R. (2011). Autophagy as a target for anticancer therapy. Nature Reviews Clinical Oncology 8, 528-539.

KASPER, M., SCHNIDAR, H., NEILL, G.W., HANNEDER, M., KLINGLER, S., BLAAS, L., SCHMID, C., HAUSER-KRONBERGER, C., REGL, G., PHILPOTT, M.P., ET AL. (2006). Selective modulation of Hedgehog/GLI target gene expression by epidermal growth factor signaling in human keratinocytes. Mol. Cell. Biol. 26, 6283-6298.

KATOH, Y., AND KATOH, M. (2009). Hedgehog target genes: mechanisms of carcinogenesis induced by aberrant hedgehog signaling activation. Curr. Mol. Med. 9, 873-886.

KOMADA, M., SAITSU, H., SHIOTA, K., AND ISHIBASHI, M. (2008). Expression of Fgf15 is regulated by both activator and repressor forms of Gli2 in vitro. Biochem. Biophys. Res. Commun. 369, 350-356.

KRÜGER, M., MENNERICH, D., FEES, S., SCHÄFER, R., MUNDLOS, S., AND BRAUN, T. (2001). Sonic hedgehog is a survival factor for hypaxial muscles during mouse development. Development 128, 743-752.

KURITA, S., MOTT, J.L., ALMADA, L.L., BRONK, S.F., WERNEBURG, N.W., SUN, S.-Y., ROBERTS, L.R., FERNÁNDEZ-ZAPICO, M.E., AND GORES, G.J. (2010). GLI3-dependent repression of DR4 mediates hedgehog antagonism of TRAIL-induced apoptosis. Oncogene 29, 4848-4858.

LAZOVA, R., KLUMP, V., AND PAWELEK, J. (2010). Autophagy in cutaneous malignant melanoma. J. Cutan. Pathol. 37, 256-268.

LISANTI, M.P., MARTÍNEZ-OUTSCHOORN, U.E., CHIAVARINA, B., PAVlideS, S., WHITAKER-MENEZES, D., TSIRIGOS, A., WITKIEWICZ, A., LIN, Z., BALLIET, R., HOWELL, A., ET AL. (2010).
Understanding the "lethal" drivers of tumor-stroma co-evolution: emerging role(s) for hypoxia, oxidative stress and autophagy/ mitophagy in the tumor micro-environment. Cancer Biol. Ther. 10, $537-542$.

MACHOLD, R., HAYASHI, S., RUTLIN, M., MUZUMDAR, M.D., NERY S., CORBIN, J.G., GRITLI-LINDE, A., DELLOVADE, T., PORTER, J.A., RUBIN, L.L., ET AL. (2003). Sonic hedgehog is required for progenitor cell maintenance in telencephalic stem cell niches. Neuron 39, 937-950.

MADISON, B.B., MCKENNA, L.B., DOLSON, D., EPSTEIN, D.J., AND KAESTNER, K.H. (2009). FoxF1 and FoxL1 link hedgehog signaling and the control of epithelial proliferation in the developing stomach and intestine. J. Biol. Chem. 284, 5936-5944.

MAITAH, M.Y., ALI, S., AHMAD, A., GADGEEL, S., AND SARKAR, F.H. (2011). Up-regulation of sonic hedgehog contributes to TGF- $\beta 1$-induced epithelial to mesenchymal transition in NSCLC cells. PLoS ONE 6, e16068.

MAO, L., XIA, Y.-P., ZHOU, Y.-N., DAI, R.-L., YANG, X., DUAN, S.-J., QIAO, X., MEI, Y.-W., HU, B., AND CUI, H. (2009). A critical role of Sonic Hedgehog signaling in maintaining the tumorigenicity of neuroblastoma cells. Cancer Sci. 100, 1848-1855.

MILL, P., MO, R., HU, M.C., DAGNINO, L., ROSENBLUM, N.D., AND HUI, C.-C. (2005). Shh controls epithelial proliferation via independent pathways that converge on N-Myc. Dev. Cell 9, 293-303.

MILLA, L.A., CORTES, C.R., HODAR, C., Q., ONATE, M.G., CAMBIAZO, V., BURGESS, S.M., AND PALMA, V. (2012). Yeast-based assay identifies novel Shh/Gli target genes in vertebrate development. BMC Genomics $13,2$.

MIZUSHIMA, N. (2007). Autophagy: process and function. Genes Dev. 21, 2861-2873.

MOHAN, N., BANIK, N.L., AND RAY, S.K. (2011). Combination of $\mathrm{N}$-(4-hydroxyphenyl) retinamide and apigenin suppressed starvation-induced autophagy and promoted apoptosis in malignant neuroblastoma cells. Neurosci. Lett. 502, 24-29.

MORROW, D., CULLEN, J.P., LIU, W., GUHA, S., SWEENEY, C., BIRNEY, Y.A., COLLINS, N., WALLS, D., REDMOND, E.M., AND CAHILL, P.A. (2009). Sonic Hedgehog induces Notch target gene expression in vascular smooth muscle cells via VEGF-A. Arterioscler. Thromb. Vasc. Biol. 29, 1112-1118.

NEUZIL, J., STANTIC, M., ZOBALOVA, R., CHLADOVA, J., WANG, X., PROCHAZKA, L., DONG, L., ANDERA, L., AND RALPH, S.J. (2007). Tumour-initiating cells vs. cancer "stem" cells and CD133: what's in the name? Biochem. Biophys. Res. Commun. 355, 855-859.

O'BRIEN, C.A., POLLETT, A., GALLINGER, S., AND DICK, J.E. (2007). A human colon cancer cell capable of initiating tumour growth in immunodeficient mice. Nature 445, 106-110.

READ, T.-A., FOGARTY, M.P., MARKANT, S.L., MCLENDON, R.E., WEI Z., ELLISON, D.W., FEBBO, P.G., AND WECHSLER-REYA, R.J. (2009). Identification of CD15 as a marker for tumor-propagating cells in a mouse model of medulloblastoma. Cancer Cell 15, 135-147.

RICHARDSON, G.D., ROBSON, C.N., LANG, S.H., NEAL, D.E., MAITLAND, N.J., AND COLLINS, A.T. (2004). CD133, a novel marker for human prostatic epithelial stem cells. J Cell Sci 117, 3539-3545.

SÁNCHEZ, P., HERNÁNDEZ, A.M., STECCA, B., KAHLER, A.J., DEGUEME, A.M., BARRETT, A., BEYNA, M., DATTA, M.W., DATTA S., AND RUIZ I ALTABA, A. (2004). Inhibition of prostate cancer proliferation by interference with SONIC HEDGEHOG-GLI1 signaling. Pnas 101, 12561-12566.

SASAKI, H., HUI, C., NAKAFUKU, M., AND KONDOH, H. (1997). A binding site for Gli proteins is essential for HNF-3beta floor plate enhancer activity in transgenics and can respond to Shh in vitro. Development 124, 1313-1322.

SCHIAPPARELLI, P., SHAHI, M.H., ENGUITA-GERMÁN, M., JOHNSEN, J.I., KOGNER, P., LÁZCOZ, P., AND CASTRESANA, J.S. (2011) Inhibition of the sonic hedgehog pathway by cyplopamine reduces the CD133+/CD15+ cell compartment and the in vitro tumorigenic capability of neuroblastoma cells. Cancer Lett. 310, 222-231.

SCHMIDT, M., PAES, K., DE MAZIÈRE, A., SMYCZEK, T., YANG, S., GRAY, A., FRENCH, D., KASMAN, I., KLUMPERMAN, J., RICE, D.S., ET AL. (2007). EGFL7 regulates the collective migration of endothelial cells by restricting their spatial distribution. Development 134, 2913-2923.

SINGH, R.R., KUNKALLA, K., QU, C., SCHLETTE, E., NEELAPU, S.S., SAMANIEGO, F., AND VEGA, F. (2011). ABCG2 is a direct transcriptional target of hedgehog signaling and involved in stromainduced drug tolerance in diffuse large B-cell lymphoma. Oncogene 30, $4874-4886$. 
SIVRIDIS, E., KOUKOURAKIS, M.I., MENDRINOS, S.E., KARPOUZIS, A FISKA, A., KOUSKOUKIS, C., AND GIATROMANOLAKI, A. (2011) Beclin-1 and LC3A expression in cutaneous malignant melanomas: a biphasic survival pattern for beclin-1. Melanoma Res. 21, 188-195.

VOKES, S.A., JI, H., MCCUINE, S., TENZEN, T., GILES, S., ZHONG, S., LONGABAUGH, W.J.R., DAVIDSON, E.H., WONG, W.H., AND MCMAHON, A.P. (2007). Genomic characterization of Gli-activator targets in sonic hedgehog-mediated neural patterning. Development 134, 1977-1989.

VORONOVA, A., FISCHER, A., RYAN, T., AL MADHOUN, A., AND SKERJANC, I.S. (2011). Ascl1/Mash1 is a novel target of Gli2 during Gli2-induced neurogenesis in P19 EC cells. PLoS ONE 6, e19174.

WALL, D.S., MEARS, A.J., MCNEILL, B., MAZEROLLE, C., THURIG, S., WANG, Y., KAGEYAMA, R., AND WALLACE, V.A. (2009). Progenitor cell proliferation in the retina is dependent on Notch-independent Sonic hedgehog/Hes1 activity. J. Cell Biol. 184, 101-112.

WANG, F., XU, L., GUO, C., KE, A., HU, G., XU, X., MO, W., YANG, L., HUANG, Y., HE, S., ET AL. (2011). Identification of RegIV as a novel GLI1 target gene in human pancreatic cancer. PLoS ONE 6, e18434.

WANG, X., VENUGOPAL, C., MANORANJAN, B., MCFARLANE, N., O'FARRELL, E., NOLTE, S., GUNNARSSON, T., HOLLENBERG, R., KWIECIEN, J., NORTHCOTT, P., ET AL. (2012). Sonic hedgehog regulates Bmi1 in human medulloblastoma brain tumor-initiating cells. Oncogene 31, 187-199.

WANSHURA, L.E.C., GALVIN, K.E., YE, H., FERNANDEZ-ZAPICO, M.E., AND WETMORE, C. (2011). Sequential activation of Snail1 and N-Myc modulates sonic hedgehog-induced transformation of neural cells. Cancer Res. 71, 5336-5345.

XU, L., WANG, X., WAN, J., LI, T., GONG, X., ZHANG, K., YI, L., XIANG, Z., XU, M., AND CUI, H. (2012). Sonic Hedgehog pathway is essential for neuroblastoma cell proliferation and tumor growth. Molecular and Cellular Biochemistry.

YANG, Z.-J., ELLIS, T., MARKANT, S.L., READ, T.-A., KESSLER, J.D. BOURBOULAS, M., SCHÜLLER, U., MACHOLD, R., FISHELL, G., ROWITCH, D.H., ET AL. (2008). Medulloblastoma can be initiated by deletion of Patched in lineage-restricted progenitors or stem cells. Cancer Cell 14, 135-145.

YOO, Y.A., KANG, M.H., LEE, H.J., KIM, B., PARK, J.K., KIM, H.K., KIM J.S., AND OH, S.C. (2011). Sonic hedgehog pathway promotes metastasis and lymphangiogenesis via activation of Akt, EMT, and MMP-9 pathway in gastric cancer. Cancer Res. 71, 7061-7070.

YOON, J.W. GILBERTSON, R, IANNACCONE, S, IANNACCONE, P, AND WALTERHOUSE, D. (2009). Defining a role for Sonic hedgehog pathway activation in desmoplastic medulloblastoma by identifying GLI1 target genes. Int. J. Cancer 124, 109-119.

YOON, J.W., KITA, Y., FRANK, D.J., MAJEWSKI, R.R., KONICEK, B.A., NOBREGA, M.A., JACOB, H., WALTERHOUSE, D., AND IANNACCONE, P. (2002). Gene expression profiling leads to identification of GLI1-binding elements in target genes and a role for multiple downstream pathways in GLI1-induced cell transformation. J. Biol. Chem 277, 5548-5555.

YU, M., GIPP, J., YOON, J.W., IANNACCONE, P., WALTERHOUSE, D., AND BUSHMAN, W. (2009). Sonic hedgehog-responsive genes in the fetal prostate. J. Biol. Chem. 284, 5620-5629.

ZHAO, M., QIAO, M., HARRIS, S.E., CHEN, D., OYAJOBI, B.O., AND MUNDY, G.R. (2006). The zinc finger transcription factor Gli2 mediates bone morphogenetic protein 2 expression in osteoblasts in response to hedgehog signaling. Mol. Cell. Biol. 26, 6197-6208. 